\title{
CORPORATE SOCIAL RESPONSIBILITY IN CORPORATE GOVERNANCE: THE COMMON LAW AND SHARIAH PERSPECTIVE
}

\author{
HARTINIE ABD AZIZ, ZUHAIRAH ARIFF ABD GHADAS, HUSSIN YUSRI ZAWAWI, \\ Faculty of Law and International Relations, Universiti Sultan Zainal Abidin, 21300 Terengganu Malaysia \\ hartinieabdaziz@unisza.edu.my (Hartinie Abd Aziz)* \\ zuhairahariff@unisza.edu.my (Zuhairah Ariff Abd Ghadas) \\ hussainyusri@unisza.edu.my (Hussain Yusri bin Zawawi)
}

\begin{abstract}
In the West, the concept of Corporate Social responsibility (CSR) began in the 1970s and discussions on the concept of CSR often centred on the view that is based on the customs, cultures and beliefs of the West, especially Europe and America. Under the common law, CSR is an option for the corporations to practice rather than part of the objective of the company. It is treated merely as a standard of behaviour to which a corporation subscribes in order to have good reputation in society. Under Shariah governance framework, it is a requirement for corporation to practice CSR as it is obligatory on each Muslim community to implement collective religious obligation (fardh kifayah). The Shariah perspective of CSR is commonly discussed from the perspectives of Maqasid alShari 'ah and Maslahah. This paper discusses the principles of Corporate social responsibility in corporate governance under both the Common law and Shariah perspectives. Main objective of this paper is to highlight the application of Corporate social responsibilty in conventional companies and Shariah compliance businesses. Findings of this paper will shows that, the application of CSR according to Shariah perspective would contribute to a good corporate governance in businesses and the implementation of the concept of CSR implies the commitment of the corporation to continuously upholding the noble objectives of Shari 'ah.
\end{abstract}

Keywords: CSR, Corporate Governance, Shariah

Article Received: 18 October 2020, Revised: 3 November 2020, Accepted: 24 December 2020

\section{Introduction}

Due to corporate failures over the past few years, the function of good governance, ethics and accountability have been emphasized to focus on the areas of corporate governance (CG) and ethical aspects of economic behaviour (Alshareef, 2015). The social and environmental impacts of the business conduct are becoming more significant for the stakeholders and therefore it will allows the organizations to involved proactively not only in legal and social, but also in the environmental and reputation risk management; resulting to the effectiveness and better stakeholder management in the organizational (Alshareef, 2015).

Corporate governance and the Corporate Social Responsibility are interconnected. Having good corporate governance implies that the company is having a good corporate responsibility by acknowledging the need for various stakeholder in terms of ethical, legal and communal over the shareholders' needs (Carroll \& Shabana, 2010; Jamali, 2008) . Besides, by fully engaged in CSR practices with all its aspects such as philanthropy practices might increase customer satisfaction (Yazid, 2020). Under corporate governance practices, it promotes not only the principles of ethics and fairness but as well as the principles of transparency and accountability. Corporate reputation and good financial results are commonly used for the corporation to engage in any social responsibility activities without forgetting the basic focus in increasing the shareholder value. A research done by Halal (2000) upholds that the combination of stakeholders is necessary to ensure a "corporate community" can be function to the wealth creation of organizational. The corporate community model is a model that considers organizations as a socioeconomic system where wealth is created through the partnership of stakeholders. By engaging in these partnerships, organizations are not only socially responsible, but more competitive (William E. Halal, 2010).

The difficulty under the current practices of CSR is, under the common law corporate model, CSR is 
still a choice to be practiced instead of part of the objective of the company. The need of CSR is still been criticising among companies. Some of them believe, a business need to be socially responsible for its long-term self-interest however there are those who think CSR will undermine the primary business goals. According to Milton Friedman, it is not the responsibility of management to resolve any social issues in the society since the management has only one responsibility that is to maximize the profit of the owner or shareholder and thus social problems are not the concern of the business people but the responsibility falls upon to government and legislation to do the job.(Carroll \& Shabana, 2010). However, under Islamic law, the obligation for doing CSR for a Muslim is not only being governed by al-Quran and as-Sunnah but, also it is subjected to the objective of Shariah, namely Maqasid Syariah (Abd Ghadas ZA \& Abd Aziz H., 2019). This paper discusses the principles of CSR in corporate governance under both the Common law and Shariah perspectives. Main objective of this paper is to highlight the difference application of CSR in conventional companies and Shariah compliance businesses. The outcome of this paper will indicates the application of CSR according to Shariah perspective would contribute to a good corporate governance in businesses and the implementation of the concept of CSR continuously implies the application of the noble objectives of Shari 'ah.

\section{Common Law Perspectives On}

\section{Corporate Social Responsibility}

The discussions of the concept of CSR which began in the West since 1970s are often centred on views based on Western customs, cultures and beliefs, especially Europe and America (Muhammad Yasir \& Zakaria Bahari, 2011). The conventional CSR has become a normal activity for a corporate to build good reputation in society as one of marketing strategy. Nonetheless the improvement of CSR in the West today needs a thorough analysis from an Islamic perspective (Dusuki, 2008).
Corporate social responsibility simply means when a company is having responsibilities and taking actions beyond their legal duties and business aims. There are many available definitions of CSR which led to the ambiguity on how to defined it (Dahlsrud, 2008). According to Hassan and Harahap, “While there is no single, commonly accepted definition of CSR, it generally refers to business decision making linked to ethical values, compliance with legal requirements, respect for people, involvement in social activities, communities, and the environment" (Hassan \& Harahap, 2010).

CSR is a standard of behaviour of a corporation in order to have a positive and productive impression from society. However, according to Hayek (1969), to implement CSR in the business would place the business into activities that are distinct from their 'proper aim'(Carroll \& Shabana, 2010). Ashraf (2008) highlighted that the growing of market and regulatory pressure becomes a driving forces behind the growing trend of CSR, wherein it is believes that a business should not only be socially responsible to various stakeholders to pursuit its profit but also they have to abide regulations by the government. It is because any conduct of the business will attract the attention of the public in terms of pricing, branding as well as social and ethical issues that give an effect to the business performance. Apart from that, the advance growth medium of communication in has encouraged consumers and any social activists, non-governmental organizations (NGOs) and trade unions to more effectively review the activities of companies and thus it will strengthen the business brand and improve their corporate reputation with customers and suppliers (Wajdi Dusuki, 2008).

\section{Corporate Social Responsibility From Shariah Perspective}

In order to protect the social justice and welfare for the society, it is a need for businesses to integrate the engagement of their businesses and CSR activities in Shariah governance framework. One of the current developments of corporate governance in the Western country is to promote the Corporate Social Responsibility (CSR) which 
is now a renowned concept all over the world but not a new concept in Islam (Mizushima, 2013). The discussion on CSR from an Islamic view covers various perspectives for example, it is obligatory for Muslim to carry out the social duty in the society. Performing CSR by Islamic banks is a collective religious obligation (fardh kifayah). Besides, CSR can be achieved by following the Maqasid Shariah effectively taking into consideration of the Maslahah of the public.

Generally, the concept of CSR is based on religious values resulting from the principle of 'ibadah and da'wah (Muhammad Yasir \& Zakaria Bahari, 2011; Wan Jusoh, Ibrahim, \& Napiah, 2015). Man was created by Allah to be the vicegerent in this world as mentioned in Surah Al-An'am :165, "It is He who hath made you (His) agents, inheritors of the earth: He hath raised you in ranks, some above others: that He may try you in the gifts He hath given you: for thy Lord is quick in punishment: yet He is indeed Oft-forgiving, Most Merciful." [Qur'an, Al-An'am: 165]

Based on the above verse, Man is created as a caliph of Allah which carries specific duty and responsibility to manage the world according to the teaching of Islam in order to ensure that justice is maintained. Besides it is the social responsibility of Muslims to always benefit the people and they cannot cause harm in any form on this earth.

In addition, social responsibility in Islam can be found from the hadith of the Prophet: "Abdullah ibn 'Umar reported: The Messenger of Allah, peace and blessings be upon him, said, "Every one of you is a shepherd and is responsible for his flock. The leader of the people is a guardian and is responsible for his subjects: a man is the guardian of his family and is responsible for his subjects, a woman is the guardian of her husband's home and of his children and is responsible for them, and the slave of a man is a guardian of his master's property and is responsible for it. Surely, every one of you is a shepherd and responsible for his flock." (Sahih Bukhari, No. 7138, 1229).

Thus, the hadith shows that every individual is accountable and responsible towards others be it as a leader, husband, wife and even a slave. Islam has shown us a wonderful system in a way to protect each individual's interests and consequently the rights of each party are protected.

Helping other people is a social responsibility as a Muslim and regarded as a good deed ('amal salih) in order to get Allah's blessing. Apparently social responsibility is a very impressive concept and practice which has been rooted in Islamic teaching fundamentally. In fact, Allah promise to reward for those who doing a social responsibility for the pleasure of Allah. Undoubtedly, this concept can be extend to all natural or artificial persons such as businesses and corporation.(Wan Jusoh et al., 2015).

\section{The Context Of Maqasid Al-Shari'Ah And Maslahah On Corporate Social Responsibility}

The creation of social justice and serving public interests are some of the important approach to achieve the Maqasid al Shari 'ah. The Qur'an says: "It is not righteousness that you turn your faces towards East or West; but it is righteousness- to believe in Allah and the Last Day and the Angels, and the Book, and the Messengers; to spend of your substance, out of love for it, for your kin, for orphans, for the needy, for the wayfarers, for those who ask; and for the freeing of captives; to be steadfast in prayer, and practice regular charity; to fulfill the contracts which you make; and to be firm and patient in pain and adversity and throughout all period of panic. Such are the people of truth, good consciousness." (Surah Baqarah, 2:177)

Maqasid Shariah means the objective of the Shari'ah to protect the five basic necessities of mankind such as protecting their faith (din), their human self (nafs), their intellect ('aql), their lineage (nasl) and their wealth (mal) (Chapra, n.d.) The uniqueness of Maqasid Shariah is, it is not only confine to the five basic necessities as mentioned earlier, but also it can be extended to other aspect of human being such as connecting the dots between the Big Five personality with innovative behaviour (Hamdy et al., 2019) as well as been used as measurement approach of Quality of Life 
for a drug-abuse inmates(A. El-Gamal, 2001). It should be noted that, any good deeds or Corporate Social Responsibility of the Muslim including corporations and all business entities must be done with the aims and intention to get the pleasure and blessing from Allah (S.W.T).

\section{THE RELATIONSHIP OF CSR AND MASLAHAH}

The term Maslaha can be interpreted as benefit, welfare or interest. Some modern Muslim scholars, divided Maslahah into three categories such as: Daruriyyat (the essentials), Hajiyyat (the complementary), and Tahsiniyyat (the embellishments). Using the principles of maqasid shari'ah and maslahah in the CSR, a corporate or management can use the three categories to make a decision when implementing CSR as well as to avoid any conflicts of interest that may arise from stakeholders.

The importance of Dharuriyat in CSR is to safeguard the basic necessities of stakeholders such as religion, life, intellect, posterity and property as well as public good in general for example by providing them safety and healthy workplace and adequate prayer rooms to employees. Secondly, the importance of Hajiyyat in CSR is to eliminate any hardship that may be faced by the person even though it may not give any danger to the basic necessities of stakeholder for example giving training and enhancement human quality programs to the employees to produce a skills worker for the company and lastly, the importance of Tahsiniyyat in corporate social responsibility is to participate in communal activities or programs that may lead to the growth of public life such as giving contribution, donation or endowment to the group of asnaf such as the poor and needy.

\section{Observation}

There are differences between the conventional theory of CSR and Islam. Corporate social responsibility in Islam is originated from the religious values. The application of maqasid Shari'ah and maslahah are very important since these principles are regarded as the most effective methods to solve any issues in corporate governance.

Secondly, it is observed that, the corporate governance in the west and in Islam have similar general objectives of corporate governance i.e to provide efficiency in management, disclosure and transparency as well as for long-term corporate stability(M. Hafeez, 2013). However, the distinguishing features of between the two governance frameworks are based on the epistemology, objectives and the management of the boards. Under Shariah governance framework, it has two-tier board i.e board of directors and Shariah board committee. Shari'ah board plays the vital role to determine the compliance of Shariah principles in all activities of corporation. Thus, by having two separate boards management, it will minimise the conflict of interest as happened in conventional governance. The shareholders did not only focus on maximizing their profit, however, he is also playing a role as an active stakeholder in the decision making process by taking into account the interest of all stakeholders. Consequently, it will improve the function of social wellbeing for the welfare in the society. All of these approaches are aimed toward satisfying the primary objective of Shariah corporate governance to protect the rights of all stakeholders in order to uphold the principle of distributive justice(Hasan, 2009)

\section{Conclusion}

Nowadays, CSR becoming a trend for a company even though there are a lot of criticism which against the practice of CSR. Most of the company incline to integrate the concept of CSR in the corporate governance of the company. Good corporate responsibility will reflects a good governance of the company which gives them a high reputation to attract the institutional investors who are very concerned with their ethical investment.

In Islam, considering the interest of the public is very important rather than individual interests. The Maqasid Shariah and Maslahah provide a framework for corporation in making decisions in managing their businesses and CSR activities 
according to priorities of the three level of maslahah. It also offers a general guideline for managers of corporations as a filter mechanism to resolve the ethical conflicts that unintentionally appear while applying CSR programs and initiatives. The concept of Maslahah also requires understanding the Islamic principle of avoiding any harmful activities to others while involving in its business and economic activities.

Consequently, the implementation of Corporate social responsibility continuously indicates the realizing of the objectives (Maqasid) of Shari'ah. Thus, based on the above discussion, it shows that, any corporation who integrate the CSR as part of their corporate governance are actually protecting the five basic necessities of Maqasid Shariah according to the priority of Maslahah which definitely contribute to a good corporate governance in businesses.

\section{Acknowledgement:}

This research is supported by the Malaysia Ministry of Higher Education Fundamental Research Grant Scheme FRGS/1/2016/SSI10/UNISZA/01/1 (RR 211)

\section{References}

[1] Abd Ghadas ZA \& Abd Aziz H. (2019). Analysis on the Doctrine of Limited Liability Under Company Law and Sharī'Ah. Al-Shajarah: Journal of the International Institute of Islamic Thought and Civilization (ISTAC), 24(2), 293-310.

[2] El-Gamal, M. (2001). An Economic Explication of the Prohibition of Gharar in Classical Islamic Jurisprudence. Journal of Islamic Economic Studies, 08-2(2), 29-58.

[3] Alshareef, M. N. (2015). Integration of corporate social responsibility (CSR) into corporate governance: New model, structure and practice: A case study of Saudi company. European Journal of Accounting Auditing and Finance Research, 3(5), 1-19.

[4] Carroll, A. B., \& Shabana, K. M. (2010). The business case for Corporate Social
Responsibility: A review of concepts, research and practice. International Journal of Management Reviews, 12(1), 85-105. https://doi.org/10.1111/j.1468-

2370.2009.00275.x

[5] Chapra, M. U. (n.d.). The Future of Economics: An Islamic Perspective. Leicester: The Islamic Foundation.

[6] Dahlsrud, A. (2008). How corporate social responsibility is defined: an analysis of 37 definitions. Corporate Social Responsibility and Environmental Management.

https://doi.org/10.1002/csr.132

[7] Dusuki, A. W. (2008). What Does Islam Say about Corporate Social Responsibility? Review of Islamic Economics, 12(1), 5-28.

[8] Hamdy, A., Fazida, K., Rashidah, M. I., Asyraf, A., Ahmad, M. bin S., Mohd, H. H., \& Mahadzirah, M. (2019). Connecting the dots between the Big Five and innovative work behaviour: Maslow and Maqasid AlShari'a Perspectives. Espacios, 40(27).

[9] Hasan, Z. (2009). Corporate governance: Western and Islamic perspectives. International Review of Business Research Papers, 5(1), 277-293. Retrieved from http://www.bizresearchpapers.com/attach ments_2009_01_13/23.Zulkipli.pdf

[10] Hassan, A., \& Harahap, S. S. (2010). Exploring corporate social responsibility disclosure: the case of Islamic banks. International Journal of Islamic and Middle Eastern Finance and Management, 3(3), 203-227.

https://doi.org/10.1108/175383910110724 17

[11] Jamali, D. (2008). A Stakeholder Approach to Corporate Social Responsibility: A Fresh Perspective into Theory and Practice. Journal of Business Ethics, 82(1), 213-231. https://doi.org/10.1007/s10551-007-95724

[12] M. Hafeez, M. (2013). Analysis of Corporate Governance in Islamic and 
Western. International Journal of Business, Economics and Law, 2(3), 98-103.

[13] Mizushima, T. (2013). Corporate Governance and Shariah Governance at Islamic Financial Institutions: Assessing from Current Practice in Malaysia. Reitaku Journal of Interdisciplinary Studies, 22(1), 59-84.

[14] Muhammad Yasir, Y., \& Zakaria Bahari. (2011). Islamic corporate social responsibility in Islamic banking: Towards poverty alleviation. 8th International Conference on Islamic Economics and Finance, 1-29. Retrieved from http://www.iefpedia.com/english/wpcontent/uploads/2011/12/Muhammad.Yasi r_.pdf

[15] Wajdi Dusuki, A. (2008). Understanding the objectives of Islamic banking: a survey of stakeholders' perspectives. International Journal of Islamic and Middle Eastern Finance and Management, 1(2), 132-148. https://doi.org/10.1108/175383908108809 82

[16] Wan Jusoh, W. N. H., Ibrahim, U., \& Napiah, M. D. M. (2015). An Islamic Perspective on Corporate Social Responsibility of Islamic Banks. Mediterranean Journal of Social Sciences, 6(2), 308-315. https://doi.org/10.5901/mjss.2015.v6n2s1p 308

[17] William E. Halal. (2010). Corporate Community: A Theory of the Firm Uniting Profitability and Responsibility. Strategy \& Leadership. https://doi.org/10.1108/SL-062015-0054

[18] Yazid, A. S. (2020). Does Corporate Social Responsibility Activities Have a Role in Creating Customer Satisfaction and Customer Loyalty? Journal of Research on the Lepidoptera, 51(2), 106-123. https://doi.org/10.36872/lepi/v51i2/301082 